\title{
Contested Statehood and State-building in Haiti*
}

\author{
Estatalidad en disputa y construcción del Estado en Haití
}

\section{STEPHEN BARANYI}

University of Ottawa

\begin{abstract}
This article bridges global and Haiti-specific debates on statehood, the political economy of state and state (de)formation, as well as the conceptualization and measurement of those phenomena. Drawing on data sets and secondary literatures from Haiti and beyond, it argues that despite the unique features of the extremely weak state in Haiti, that case can usefully be compared to the range of weak to fairly strong states in Latin America and the Caribbean. In the process, the article makes a case for considering degrees of sovereignty as an integral dimension of statehood in the region and elsewhere. It demonstrates the relevance of concepts used in other articles in this volume, such as 'weakness by design', in the Haitian case. The article ends by suggesting that it would be useful to look beyond neo-Weberian theories, for example by incorporating critical feminist analysis, to understand the different faces of state weakness and their social construction in the region.
\end{abstract}

Key words: Haiti Statehood, State-building, Conceptualization and Measurement.

\section{RESUMEN}

El presente artículo tiende un puente entre los debates globales y específicos de Haití sobre estatalidad, la economía politica de la (de)formación del Estado y la conceptualización y medición de dichos fenómenos. Basándose en datos y literatura secundaria sobre Haití, pero sin circunscribirse a este caso, el presente artículo sostiene que a pesar de los rasgos característicos del Estado extremadamente débil de Haití, dicho caso puede ser comparado productivamente con una serie de otros estados, que van desde estados débiles a relativamente fuertes, en América Latina y el Caribe. En el proceso, el artículo sugiere considerar a los niveles de soberanía como una dimensión integral de la estatalidad en la región, pero también en otras partes del mundo. El artículo demuestra la relevancia de conceptos utilizados en otros artículos de este volumen, como el de "debilidad por diseño", para el caso de Haití. El artículo concluye sugiriendo que sería útil ir más allá de las teorías neoweberianas, por ejemplo incorporando análisis críticos feministas, para entender las diferentes caras de la debilidad estatal y su construcción social en la región.

Palabras clave: Estatalidad en Haití, construcción del Estado, conceptualización y medición.

* This article is part of the Millenium Nucleus for the Study of Stateness and Democracy in Latin America, Project NS100014, of the Ministry of Economy and Tourism of Chile. 


\section{HISTORICAL-COMPARATIVE SNAPSHOTS}

The earthquake that destroyed several cities, killed an estimated 300,000 Haitians and displaced over 1 million more in January 2010, also levelled the state. ${ }^{1}$ In the days following the shocks, President Préval was seen wandering in a daze, his palace in ruins, unable to make authoritative declarations to his citizens. Surviving officials were unable to lead relief or security operations. Those tasks were taken over first by the United States, which despatched over 10,000 troops to Haiti within days, then by the United Nations and the myriad of international NGOs that descended on Haiti to respond to the tragedy. Ordinary Haitians, without much support from 'their' state or from the international community, took on the less visible tasks of caring for the wounded, sheltering homeless relatives, securing potable water and protecting their communities (Manigat, 2010).

The institutional fragility laid bare by the earthquake has deep historical roots. Scholars such as André Corten (2011) and Robert Fatton (2007) have situated the origins of Haiti's weak state in the legacies of French colonialism, the social construction of a despotic but fragmented post-colonial state in the 1800s, the superficial modernization of the state under US occupation, the reengineering of those institutions by two Duvalier dictatorships, and the degeneration of the state under the populism of President Aristide. Others such as Dupuy (2005) and Deshommes (2006) have suggested that the neo-liberal structural adjustments initiated at the end of the Duvalier era and continued (due to Western pressure) under Presidents Aristide and Préval in the 1990s, retrenched the state and devastated the agricultural sector, generating massive rural-urban migration in their wake. The historical interplay of poor governance and uneven economic development, and the more recent impacts of market-oriented reforms and chaotic urbanization, are often cited as factors explaining the devastating impacts of the 2010 earthquake, despite the relatively low intensity of the quake itself. ${ }^{2}$

Given that historical trajectory, it is not surprising that Haiti was ranked the fifth weakest state in the world on the Failed States Index (FSI) in 2011, right between the Democratic Republic of Congo and Zimbabwe (Fund for Peace 2012). That year, it was the only Latin American and Caribbean country that was placed in the Fund's 'alert' category, far above states like Colombia ( $\left.44^{\text {th }}\right)$, Bolivia (59th) and Nicaragua $\left(66^{\text {th }}\right)$ which were only placed in the 'warning' category -and worlds apart from Costa Rica $\left(137^{\text {th }}\right)$, Argentina $\left(145^{\text {th }}\right)$ and Chile $\left(153^{\text {rd }}\right)$, whose state strength was ranked at the level of countries in eastern and southern Europe.

1 These are the official estimates by the Government of Haiti (2010a). Based on a rigorous follow-up survey, Schwartz and Pierre (2011) estimated that under 85,000 people actually perished as a result of the earthquake. Nonetheless, I cite the official estimates since they still dominate the international narrative on the disaster.

2 According to the US Geological Survey, the earthquake that struck $25 \mathrm{~km}$ south of Port-au-Prince in Haiti on January 12, 2010 measured 7.0 on the Richter scale. In comparison, the earthquake that struck $100 \mathrm{~km}$ west of Concepcion in Chile on February 27, 2010, measured 8.8, killed approximately 525 people and displaced 800,000 more. See http://earthquake.usgs.gov/earthquakes/eqinthenews/2010/ us2010tfan/\#summary. 
Despite its methodological limitations, one noteworthy aspect of the FSI is its use of 12 indicators of fragility: some cover what Mazzuca (in this volume) calls the 'holy trinity' of statehood (autonomy, capacity and legitimacy), while others cover economic, social and international dimensions of vulnerability. Looking carefully at the 2011 index, we see that Haiti ranked at the top because of its very high score for the state's incapacity to deliver core public services $(10 / 10)$ as well as its poor governance and low state legitimacy (9.4/10). Yet Haiti's high fragility ranking also reflects broader conditions like mounting demographic pressures $(10 / 10)$, population displacement $(9.2 / 10)$, economic decline and extreme poverty (9.2/10). Finally, it reflects the preponderant influence of external actors, including the large presence of foreign security forces (10/10). The latter indicator seems especially relevant as a marker of state weakness in Haiti and in other Caribbean societies (from Cuba to Martinique), where despite significant differences, the presence of foreign security forces is a salient marker of limited sovereignty -de jure and de facto, today and historically.

What does the Haitian case, as well as the way its statehood has been interpreted and quantified, suggest about the challenges and possibilities for conceptualizing, measuring and understanding statehood in Latin American in the Caribbean (LAC) or in other parts of the world? Let me address that question by selectively engaging with some of the ideas put forward in the introductory article by Feldmann and Luna (2011) as well as in some other articles in this volume. I will do so through a reading of the Haitian case that privileges analyses by Haitian and Diaspora scholars, since their diverse perspectives are not widely known beyond Haiti and North America. I will also touch on existing metrics like the FSI as well as on the broader state-building literature which contributors to this volume were encouraged to address.

The tools we select to categorise and explore statehood depend not only on our philosophical and methodological orientations, but also on the ultimate aim of our analyses. Is our collective aim only to compare degrees of statehood in different Latin American and the Caribbean countries, as well as across territories in each country? Is it also to understand how those degrees of statehood were socially constructed and contested over time? Are we mainly speaking to scholarly debates on the state of the state in LAC? Or, as suggested by Feldmann and Luna in their article, do we also wish to shed light on options for practitioners, namely for national and international 'statebuilders'?

Taking my lead from Feldmann and Luna (2011), I assume that our collective aspirations include all those aims, even though we may not share them in equal measure. Without delving deeply into policy options for Haitian and international actors, this article address the theoretical as well as the practical dimensions of contested statehood in Haiti. Indeed, one could argue that building an effective and legitimate state is one of Haiti's central development challenges today. My reflections are therefore framed by that maximalist agenda rather than only by the desire to compare statehood in Haiti to other situations in LAC. 


\section{HAITI AND THE CONCEPTUALIZATION OF STATEHOOD}

It is hard to disagree with the neo-Weberian wisdom noted by Feldmann and Luna (2011) and by the authors of several other articles that:

- statehood is a set of attributes which states manifest in different degrees over time (history), space (territorial reach) and domain of activity (scope);

- its core attributes are the administrative capacity to deliver essential public services (like security, governance and basic infrastructure) and raise revenues for those public goods;

- another core attribute is the legitimacy of the state in the eyes of its citizens.

The capacity dimension corresponds roughly to what Mann (1986) called 'infrastructural power', while the legitimacy dimension reminds us that statehood is a relational phenomenon shaped by the interplay between socially-constructed administrative capabilities and the societal recognition of state authority. Haiti certainly fits into that basic conceptual frame, at the bottom end of a hypothetical statehood spectrum or at the top end of state fragility indices like the FSI. In this section I will speak to the dimensions of statehood in Haiti in conceptual terms, leaving more detailed empirical data and measurement issues for the following section.

With regards to state capacities, the limited ability to finance and administer core public goods like a citizen registry, elections, rule of law, basic education and transportation infrastructure are salient features of state weakness in Haiti today. Outsiders are often surprised to see how little the central state is present outside the capital and a half dozen other cities. Beyond those urban centers, there are rarely any state security posts, courts, paved roads, public hospitals or even clinics, agricultural extension services or secondary schools. Where they exist, they have often been built and maintained by foreign nongovernmental organisations (NGOs). Since 2004, security and elections have to a large extent been financed and administered by international actors working under the UN Stabilization Mission in Haiti (MINUSTAH).

Those patterns have led Diaspora scholars such as Holly (2012) to update Wargny's classic judgement (2004) that the Haitian state 'does not exist' since it has been historically deformed by predatory elites, supplanted by the United States and further displaced by the UN since the intervention in 2004. There is some truth to that view, certainly as a reflection of the subjective perceptions of some Haitians. Yet it minimises salient sociological facts like the legal and material existence of state institutions, as well as the historical agency of certain Haitian leaders. For example, it downplays the reappropriation of certain aspects of governance, planning, taxation, service delivery and diplomatic representation, by the government that emerged from the elections of 2006 (Baranyi, 2011). As we shall see, it also misses the drive by President Martelly to reassert national will since his election in 2011, for example by beginning to revive a defence force, against the clear preferences of Western powers and the UN.

Furthermore, the discourse of 'Haiti n'existe pas' downplays the existence and work of state institutions at the sub-national level. Building on the organs of local control 
established by the Duvalier regimes, the Constitution of 1987 codified measures to democratise and strengthen the 'collectivités territoriales' and enable them to deliver certain services, particularly in rural areas where the central state was known to have a limited presence. Although some 'collectivités' have developed rudimentary capacities for self-governance and informal justice, the real strength of those local institutions seems to be modest given that they have no taxation powers and little administrative infrastructure (Dorvilier, 2011). More fieldwork is certainly required to map territorial variations in degrees of statehood at the local level.

Kurtz and Schrank (in this volume) have suggested that our analysis of statehood should put aside the legitimacy dimension since it is too difficult to measure. Despite that methodological challenge, it is essential to examine the legitimacy dimension in the Haitian case because low public confidence in particular governments, institutions and in the state as a whole ${ }^{3}$ has been a major issue in Haiti historically and remains so today.

For example, since 2011 many national and international actors have questioned the legitimacy of the current government because President Martelly won 65\% of the votes in run-off elections in March 2011 - but $65 \%$ of only about $20 \%$ of eligible electors who voted in that round. The low voter turn-out reflected voter apathy but it also reflected the call, by social movements and opposition parties, for a boycott of the second round. Their call was partly a reaction to the backing that Mr. Martelly received from certain Western states and public relations firms, after the Electoral Council initially excluded him from the run-off (Seitenfus, 2011). Since the election and after months of resisting Martelly's attempts to form a cabinet, in early 2012 the National Assembly launched an investigation into Mr. Martelly's nationality based on the allegation that his dual citizenship was unconstitutional and that he should therefore resign.

Those events highlight the interplay between the contested legitimacy of particular governments, institutions such as the Presidency and the Electoral Council (which is still 'provisional' after over two decades!) and the broader Haitian state. It is such developments that led Gilles (2011) to argue that there are tensions between several forms of state legitimacy ('logiques de légitimité') in Haiti: legitimacy based on Western rational-legal norms and promoted by the international community; legitimacy based on popular appeal, as practiced by former President Aristide; and patrimonial legitimacy rooted in a tradition of strong-man leaders who used power and resources to control their followers, neutralise opponents and keep foreign interveners on the margins of real politics. Others such as Fatton (2007) have looked at those discursive phenomena through more historical materialist lenses, but they agree that the contestation of particular rulers' and broader state legitimacy has been a constitutive characteristic of the Haitian state since it achieved formal independence in 1804. Given the salience and intense conflicts over governmental and wider state legitimacy in Haiti, it would seem unwise to leave this out of a conceptualization of statehood, in this case and probably

3 In this volume, Mazzuca usefully distinguishes between the legitimacy of particular governments, other state institutions and the state as a whole. 
in other highly contested LAC states. The problem of low levels of state legitimacy is also a persistent theme in the literature on state formation and state weakness in subSaharan Africa (Bayart, 1989; Young, 1994).

A practical reason for including the legitimacy dimension is that the international policy and scholarly literatures on state-building have moved this dimension from the periphery to the center of their concerns in recent years. Since 2008, the OECD/DAC International Network on Conflict and Fragility (INCAF) has published four major documents criticizing the failures of post-9/11 state-building efforts for focusing too much on security first and secondly on strengthening other state institutions. INCAF's recent (2011) policy guidance urges donors to complement institution-building projects with efforts to foster the negotiation of new state-society contracts and the reconfiguration of state legitimacy.

In its 2011 World Development Report, the World Bank also called on the international community to support political coalitions that could drive policy reforms and strengthen the legitimacy of the state. That same year, OECD donors and 19 self-described fragile states (including Haiti) subscribed to a 'New Deal for Engagement in Fragile States' which put the goal of fostering 'legitimate politics' ahead of security as a core goal of international cooperation in such contexts. Those shifts have been influenced by lessons learned by certain donors and fragile states governments, but also by the emergence of post-realist, liberal revisionist scholarship on state-building in recent years (Chesterman and Thakur, 2005; Ghani and Lockhart, 2008).

In their paper, Feldmann and Luna (2011) paper urge contributors to consider whether other dimensions of statehood may be crucial for particular cases. In Haiti, I believe that weak administrative capacity and legitimacy are necessary but insufficient elements to understand statehood. The other dimension that looms large in Haiti as well as in many other Caribbean (and African) societies, as I suggested at the outset, is a rather central attribute of sovereignty: a state's ability to assert its perceived interests and authority vis-a-vis external actors, on its territory. This is not only about the monopoly on the legitimate use of violence, as some neo-Weberians would have us believe. It is also about a state (and a people) being able to identify and promote their interests in realms like economic policy and culture, as dependency theorists taught us decades ago.

Though sovereignty is a matter of degree anywhere, it is undeniable that independence is deeply compromised in the Haitian case and has been so for generations. This is highlighted by repeated foreign interventions under different guises (notably the brutal American occupation from 1915-1934, lest we forget) and by the presence of over 10,000 foreign security personnel on Haiti's territory since 2004. It is more subtly experienced through the presence of senior foreign advisors inside or close to key Haitian ministries. It is underscored by the high dependence of state and society on official development assistance: ODA is said to account for about $60 \%$ of the national budget, ${ }^{4}$ even though

4 The $60 \%$ figure for Haiti's fiscal dependence on aid (in 2009) can be compared to $199 \%$ in Afghanistan, $88.5 \%$ in Liberia or 40\% for Mail in the same year. See Action Aid 2010: 20. 
a mere $10 \%$ of ODA flows through national accounts and institutions (Action Aid, 2010; UNSG, 2012). It is precisely such conditions that lead Holly, Wargny and others to argue that the Haitian state 'does not exist'. The challenge, for social scientists, is to grasp the paradox of juridical and material statehood, limited (but real) Haitian state agency, dependence and enduring aspirations for greater de facto sovereignty.

One cannot overemphasize how important sovereignty is to Haitians and to others in the greater Caribbean. Their worldview has historical roots in the discourse of anticolonial struggle and independence which Haitians introduced to the southern part of the Americas over 210 years ago. Those ideals are regularly invoked by national and regional leaders precisely because they have been so difficult to attain in practice -in Haiti, Honduras, Nicaragua, Panama, in English-speaking Caribbean countries that gained their de jure independence after 1960, even in Cuba, and especially in nonindependent territories like Guadeloupe and Puerto Rico (Hillman and D'Agostino, 2009). Given the limits and salience of the struggle for empirical sovereignty in Haiti and in the sub-region, it would also seem unwise to exclude that dimension from our conceptualization of statehood in LAC.

One way to include that dimension in the 'holy trinity' of statehood might be to conceptualize autonomy as having two facets reflecting the 'Janus faced' nature of the modern state: autonomy vis-a-vis powerful domestic constituencies as well as autonomy vis-a-vis major external actors (Skocpol, 1985). That may seem parsimonious and appropriate in an era where the boundaries between internal and external actors are blurred. Yet the conflation of autonomy from such legally distinct actors seems ontologically problematic; it may also generate measurement problems. It seems wiser to treat (degrees of) autonomy from external actors or sovereignty as another central dimension of statehood, in addition to autonomy from domestic constituencies.

Another advantage of the Fund for Peace's Failed States Index is that it treats empirical sovereignty as a major dimension of state strength/fragility. It also provides a suit of 10 sub-indicators to operationalize that dimension and facilitate comparison with other states. Although some of those sub-indicators seem redundant, the following may help us distinguish between degrees of sovereignty in Haiti and in the greater Caribbean: covert intervention; economic intervention (e.g. embargoes); aid dependency; external support for factions; presence of foreign troops; military assistance and training; as well as police training (Fund for Peace, 2011).

\section{HAITI AND THE MEASUREMENT OF STATEHOOD}

In his suggestive article in this volume, Soifer traces the contours of an approach to measure the capacity and legitimacy dimensions of statehood, rather than the societal outcomes of that performance. He suggests that it is possible to develop metrics to measure variations in state performance across territories and core areas of activity - which he defines as the provision of security and other core public services, as well as taxation to finance those public goods. He suggests indicators that could be used for this approach. 
That approach is promising, yet the Haitian case underscores both the promise and the difficulty of operationalizing the scheme in extreme cases of state weakness. Let me illustrate this duality by casting a preliminary glance at the relevant data in this case.

With regards to the provision of public security, Soifer proposes to use data on crime rates, lynching rates and use of private security services. As he anticipated, three Latin American Public Opinion Project reports on Haiti (Zephyr et. al., 2006; 2008 and 2011) offer data on crime victimization based on robust surveys and can be compared to data on other countries. They also offer data on public confidence in police and justice institutions. One can triangulate the LAPOP findings with those from the large-N security surveys carried out by Muggah and Kolbe in other years (reported in 2011 and 2012). Together, those surveys indicate that perceptions of public security and confidence in state institutions increased considerably in 2008 and 2009, after the fairly legitimate 2006 elections and subsequent joint stabilisation operations by MINUSTAH and the Haitian National Police (HNP). They suggest that, during that period, public confidence in the HNP was remarkably higher than confidence in other rule of law institutions such as the judiciary -which is not surprising given the relative lack of progress on judicial reform during that period. Yet the latest survey by Muggah and Kolbe (2012) suggests that victimisation (especially property crime and violence against women and girls) has increased significantly since early 2011, particularly among the urban poor, and that confidence in statutory rule of law institutions has correspondingly decreased.

With about 10,000 active duty personnel, the ratio of police to citizens (1:1000) is one of the lowest in the Americas; it is far below the UN norm of 1:400 for developing countries (UNSG, 2012; ICG, 2011). According to the UN, about $84 \%$ of HNP personnel are concentrated in the capital and surrounding areas, suggesting that the state's bureaucratic coverage in the domain of public security is quite thin beyond Port-auPrince -despite the fact that over $50 \%$ of the population still resides in rural areas. Burt and others (2012) are gathering data on this rather thin public security presence as well as on the unregulated proliferation of private security firms in Haiti. Those data should also be triangulated with the results of the LAPOP and Muggah-Kolbe surveys as well as with the data being collected by the Observatoire National de la violence et la criminalité (ONAVC), to get a more complete picture of the performance of, and public confidence in, different security and rule of law institutions.

For other public services, Soifer suggests using the territorial coverage of national censuses, national identity and voter registration, and vaccination rates as indicators of state capacity. Since 1950 the fairly respected Haitian Institute of Statistics and Information (IHSI) has carried out four censuses, the last of which was conducted in 2003. The latter seems to have covered the entire national territory, but it is difficult to ascertain the depth and rigour of data gathered in rural areas without a closer analysis of the survey methodology (IHSI, 2003).

Since then, international attention has concentrated on building the capacity of the National Identification Office (ONI), given the importance of national identification for the organization of broadly-based elections. As of December 2011, ONI claimed to have registered almost five million of Haiti's estimated population of 10 million inhabitants, corresponding to just under $90 \%$ of the population aged 18 or over (ONI, 2011). 
Neither IHSI nor the Ministry of Health offers data on vaccination levels on its websites. However, Pan-American Health Organisation data indicates that Haiti's 2010 overall vaccination rate for children under one year old was $69 \%$, far below the regional average of $93 \%$ or the Dominican Republic's rate of $98 \%$ (PAHO, 2012). That data also suggests that immunization rates have fluctuated considerably over the past 15 years, from a high of $80 \%$ in 2000 before the political instability during President Aristide's second term, to a low of $43 \%$ in 2003 , gradually returning to under $70 \%$ by the end of the decade. Such limited vaccination coverage should not surprise us given the government's extremely low expenditures on public health: according to ECLAC (2011), in 2007-08 those expenditures accounted for only $5.1 \%$ of the government's budget and only $0.6 \%$ of the country's GPD -compared to the Greater Antillean and Central American averages of $11.5 \%$ of government expenditures and $3.4 \%$ of GDP.

To gage the state's revenue extraction capacity, Soifer proposes to calculate the percentage of revenues generated by income and wealth taxes divided by the percentage of revenues generated from customs and resources rents. He also suggests that the percentage of the working-age population working in informal sector could be used as a proxy for the state's taxation capacity.

The government of Haiti provides limited web-based information about taxation in the country, though the Ministry of Finance reported that only 83, 537 individuals paid income taxes to the state in 2010-2011 (Ministère des Finances, 2012). ECLAC (2012) indicates that the state's tax revenues accounted for $11.78 \%$ of the country's GDP in 2010, considerably below the LAC average of 17\% (Pages 2010). It also indicates that taxes on income, profits and capital gains (2.2\% of GDP) were lower than taxes on international trade and transactions (4.3\%) in 2010, confirming the common view that Haitian state's ability to extract revenues from its citizens remains very limited. That view is also supported by a recent OECD study (2009), which suggests that informal employment accounts for $92.6 \%$ of total non-agricultural employment in Haiti-comparable the rate in least-developed Sub-Saharan African states like Benin and much higher than rates of $75 \%$ in LAC countries like Ecuador. Nonetheless, one should also use this data with care, as its source and therefore its reliability are unclear in the Haitian case.

Finally, though Soifer shies away from suggesting exactly how one might measure state legitimacy in LAC, it is worth recalling that LAPOP offers comparative data on that dimension too. In the Haitian case, its 2008 survey reported data suggesting low levels of public confidence in the country's political institutions (36\%) and a slightly higher rate of confidence in judicial institutions (47\%), yielding an overall rate of $40 \%$ support for state institutions -controlled for presidential popularity to eliminate conflation with perceptions about particular governments. That placed Haiti close to the bottom of the confidence in state institutions index in LAC in 2008. The survey LAPOP conducted in late 2010 provided updated data on that dimension. It also offered fairly rich data on public perceptions of national and local state institutions and of their performance at the local level in some municipalities beyond the capital of Port-au-Prince. That data can be triangulated with the Muggah and Kolbe findings noted above. Together, they confirm views of the Haitian state as eliciting a very low level of public confidence. Yet they also 
show that rates of public confidence have varied by government and by institution, with bodies like the National Police gaining significant legitimacy between periods of crisis. In sum, a mixture of national statistics, LAPOP survey results and other data can be used to generate a nuanced, composite picture of the statutory provision of public goods in the domains of security, other public goods such as citizen registration, and revenue generation. LAPOP surveys offer directly comparable data on the legitimacy dimensions, nationally and to some extent locally. Obviously, that data cannot be assumed to be robust at the source -in Haiti as in some other countries of the region. Haiti can be included in a sample of LAC countries for longitudinal and comparative tracking of statehood, though its inclusion certainly poses methodological challenges.

Nonetheless, our repeated references to LAPOP surveys as well as to the Failed States Index at the outset of this article, beg the question of whether one should compile a new dataset on statehood in LAC. There are at least 12 established indices that cover multiple dimensions of statehood in the world. ${ }^{5}$ The creation and maintenance of those indexes requires a considerable amount of resources. Given that many institutions have been compiling such datasets for years or even decades in some instances, it might be wiser to identify the niches where gathering new or more robust data, and/or subjecting it to more fine-grained analysis, may contribute more to knowledge than trying to invent yet another index of statehood, even 'just' for LAC.

This scan of the existing literature and data sets suggests relevant niches in the Haitian case. One is the need to more rigorously synthesize and triangulate existing data to generate a more complete, robust and comparable picture of contemporary statehood (capacity, legitimacy and sovereignty) in Haiti. A related gap is the need to map empirical statehood beyond Port-au-Prince, in secondary cities like Cap Haïtien as well in the myriad of rural communes that dot the hills of Haiti. Yet another is the need to look more carefully at how statehood varies in different domains of social life, from taxation and sectors of the economy like agriculture where the state seems weak, to domains like public security where it has developed greater capacity and legitimacy. Perhaps the most complex challenge is to link the careful documentation of variations in statehood to the rich historical analyses of state (de)formation in Haiti. Beyond their relevance for researchers, those gaps are of great practical importance, since the urgent search for a path out of state weakness in Haiti should be informed by a rigorous understanding of the state's different manifestations and of their constitution by different actors over time.

\section{SOCIAL THEORY AND THE (DE/RE)CONSTRUCTION OF STATEHOOD}

Let me end with brief reflections on several other analytical themes raised by articles in this volume. Most of those contributions help us move beyond the description statehood as it stands today in different contexts, to understanding how statehood has

5 See Mata and Ziaja (2009) for an excellent guide to the conceptual and methodological aspects of the 12 major state fragility indexes worldwide. 
been historically constituted and contested by a multitude of social forces over time. What follow are additional reflections on how Haiti fits into those theoretical debates.

\section{Challengers and the historical constitution of fragility}

Dewey's argument (in this volume) that 'the central challenger to the State is the State itself', and Boone's view (ditto) that certain post-colonial states reflect 'weakeness by design', are both highly relevant to Haiti. As noted earlier, Wargny, Fatton and others concur that this problem can be traced to the birth of the new state in 1804, particularly to the political-military elite's strategy of militarizing the state to defend against attacks by the French and assert their dominance over domestic rivals. Certain elites' recurrent use of military or paramilitary forces to exercise their patrimonial power, and their minimal investments in the development of other state functions like the provision of public health services, are symptomatic of this 'weakness by design'.

Nonetheless, it would seem inaccurate to downplay the importance of external challengers to the development of state institutions. The first is the US which, during its occupation, its subsequent support for the Duvaliers and its direct sponsorship of extreme market-oriented reforms, clearly undermined the construction of a capable, legitimate and sovereign Haitian state. Dupuy and Deshommes have documented how the IMF, the World Bank and the Inter-American Development Bank collaborated with Washington to compel Haitian governments to dramatically reduce tariffs, sell off state assets and otherwise liberalize the economy -even though such policies were directly at odds with demands that emerged from the popular democratic movement in the late 1980s and early 1990s. ${ }^{6}$

The role of foreign NGOs in Haiti has also sparked widespread critique. Haiti was already dubbed the 'Republic of NGOs' before the earthquake. The uncoordinated proliferation of international projects since then has aggravated what Zanotti (2010) and Marcelin (2011) call the 'cacophony of aid' in the country. With support from international actors like UNDP, the Ministry of Planning and External Cooperation has created a compulsory registry of NGOs operating in the country. This may provide tools to regulate foreign NGOs and align some of their activities with national plans, or at least reduce their negative impacts on state-building.

Another major challenger is organized crime which, as noted by Dewey and others, traverses national borders and institutional boundaries. The media, the International Crisis Group and the US State Department have repeatedly suggested that the drug trade has corrupted the highest spheres of the Haitian state since the 1990s. Recent studies of police reform have noted that UN-sponsored attempts to remove allegedly criminal personnel from the force have failed due to the resistance of senior officers and government officials (Fortin and Pierre, 2011). This is an example of how membership of state institutions is contested and defended, as per Dewey's analysis. Surprisingly, 
there is little grounded, scholarly research on the details of how transnational organized crime has affected other dimensions of statehood in Haiti.

Finally, nature itself has posed major challenges to statehood in Haiti. This has manifested itself in many ways -from the mountainous topography of many zones which has complicated the construction of national infrastructure and a national market, to increasingly powerful hurricanes and of course the devastating earthquake that shook state and society to their foundations in 2010. As such, it seems imprudent to ignore the impacts of environmental forces on statehood in Haiti and the wider Caribbean -particularly if climate change continues to fuel rising sea levels and more severe tropical storms in the sub-region (Bueno et al., 2008). This also converges with the interest in how environmental factors have shaped and constrained state-building projects in subSaharan Africa (Herbst, 2000).

\section{State-building, national agency and international engagement today}

One of the many paradoxes of Haiti is that it is home to an array of contradictory domestic and foreign initiatives. Particularly since the elections of 2006 and the adoption of the Principles for Good International Engagement in Fragile States and Situations by the OECD Development Assistance Committee (DAC) a year later, many actors have claimed to be strengthening the state in Haiti. The UN and Western donors like Canada have trumpeted the need to reinforce the planning, administration and accountability functions of the central state. Research suggests that they have provided funds and technical assistance for that purpose, though most ODA has been channelled through foreign executing agencies (Baranyi, 2011).

For example, a major rethink of US assistance policy under Obama Administration placed the Haitian state at the center of its strategy, though research suggests that USAID is having even more difficulty walking the talk of strengthening the Haitian state as a matter of priority (Maguire, 2011). Argentina, Brazil and Chile also promised to develop forms of South-South cooperation that were distinct from traditional NorthSouth relations of dependency. Yet there again, scholarly analysis suggests that the ABC countries are also having difficulties putting their ideas into practice in the complicated Haitian environment (Feldmann, Lengyel et al., 2011). This Haiti-specific pattern reflects the wider policy to practice gaps that plague donor performance in fragile states despite recent reform efforts (Manning and Trzeciak-Duval, 2010).

Even in moments of great dependence on external actors, successive Haitian leaders have reminded the international community that they do have a vision of a different state. Allow me to reuse a citation from former Haitian Prime Minister Jean-Max Bellerive, originally pronounced in February 2010 and cited in a recent article (Baranyi, 2011):

We share a dream, that of seeing Haiti as an emerging country by 2030: a society of simplicity, equity, justice and solidarity, living in harmony with its environment and its culture; in a type of modernity where the rule of law, freedoms of association and expression and territorial planning are well-established; in a modern, strong, 
dynamic, competitive and open economy with a wide territorial base; where the range of people's basic needs are satisfied and are guaranteed by a strong, unitary yet decentralised state that safeguards the public interest. ${ }^{7}$

Until the end of his term, Bellerive reminded the international community about this endogenous, developmentalist vision of a strong state, a dynamic yet sustainable economy and an equitable society. He also persisted in reminding international actors that it was their duty to support the realization of this vision instead of perpetuating weakness and dependence.

Yet while the Prime Minister was raising the bar for international cooperation, his President and other leaders of the ruling Inité party were taking steps to perpetuate their party's power by undermining the independence of the Provisional Electoral Council and the therefore legitimacy of the state -in other words by keeping the key parts of the state 'weak by design'. To complicate matters, public statements in 2010-2011 suggest that in addition to wanting to hang onto their power, the political elite around Préval actually felt that they were protecting Haiti's sovereignty against the machinations of external powers- particularly the US and Canada, which wanted to see a more compliant candidate elected to the Presidency (Seitenfus, 2011). ${ }^{8}$

Policzer (in this volume) has suggested that complexity theory can help us understand such interactions between networks of national and international, state and non-state actors. That approach connects us to new institutional theories and the insights they offer into why a wide variety of actors act as they do in 'complex adaptive systems'. Complexity theory can certainly help us understand some of the 'moral hazards' that international actors have experienced in Haiti over the past decade: for example when Brazilian officers in MINUSTAH discovered that they were backing vengeance by the Government of Transition in 2004-2005, or when Western powers who supported President Martelly's election in 2010-2011 discovered that he was determined to reconstitute an army despite their opposition.

Yet in the Haitian case, more grounded research is required to nuance certain generalizations informed by complexity theory -such as Policzer's view that states remain 'the key coordinators and facilitators' in LAC. Despite the aspirations of Haitian political leaders in this regard for 25 years, this article demonstrates that the state has had great difficulty coordinating key social processes- due to the fragmentation of Haiti's elites, the patrimonial governance of its leaders and the limited capabilities of the state bureaucracy, all aggravated by rivalries between major international actors such as the West versus Cuba and Venezuela today.

Author's translation, from Bellerive (2010).

Those complications endure. The Martelly government's draft National Development Strategy (MPCE, 2012) reiterates the commitment to build a capable, modern state by 2030. At the same time, President Martelly and Prime Minister Lamote are spawning new bodies that are not clearly articulated with established institutions. For example, they have created the National Education Fund and generated sizeable revenues for that fund by increasing taxes on remittances and phone calls into Haiti. Although parliament passed a law authorising the Fund in mid-2012, the opacity of its governance and accountability mechanisms have elicited little support from the public or from traditional donors like the Inter-American Development Bank (Guy, 2012). 
Finally, if we seek to build a common yet plural research agenda on statehood in LAC and beyond, we should recall that other traditions of social thought can also help us understand such dynamics and their consequences in fragile states like Haiti. This includes the work of neo-realist scholars like Fukuyama (2004) and the liberal revisionist literature referenced earlier.

Such an exploration should also draw on more critical currents of thought on statebuilding. This article has highlighted salient works on the historical deconstruction of the state in Haiti. Broader critical scholarship includes the work of Bendaña (2008) on the fragile premises of the failed state discourse in Latin America, and on the emergence of endogenous state-building projects in countries like Bolivia and Ecuador. It includes Richmond and Newman's lucid critiques of liberal peacebuilding and state-building (Newman et al., 2009; Richmond, 2011). This current also includes post-colonial feminist perspectives on the gender dimensions of state (de)formation, (in)security and (uneven) development in the South (Peterson, 1992 and Shepherd, 2008).

Critical feminism, in particular, could contribute much to the study of statehood in LAC. How might our indices and theorizations be enriched by incorporating gendered differences in the experience of statehood -for example regarding access to public security or public health? What insights might be added by gender-disaggregated data on state legitimacy? How can we ignore the fact that it is certain men (mostly lightskinned, urban men from powerful classes) who have shaped the state in Haiti and elsewhere in LAC? Hopefully this paper will inspire the next generation of scholars working on statehood to engage with such alternative perspectives rather than staying in the comfortable flow of the new institutional mainstream.

It bears underlining that engagement with other currents of thought is not merely of theoretical interest. Engaging with feminism could help us understand the gender dimensions of statehood as well as the possibilities for agency, by women's organisations and many others, in the construction of a more inclusive state. Engaging with other critical perspectives may reveal new possibilities for transformational practices. It may also remind us of the structural and cultural legacies that make transformation extremely difficult in contexts like that of Haiti.

\section{REFERENCES}

Action Aid. 2010. Real Aid: Ending Aid Dependency. London: Action Aid.

Baranyi, Stephen. 2011. "Introduction: Peacebuilding and Reconstruction in Haiti". Journal of Peacebuilding and Development 6 (3): 3-16.

Bayart, Jean-François. 1989. L'État en Afrique. La politique du ventre. Paris: Fayard.

Bendaña, Alejandro. 2008. "Fragile Premises and Failed states: A Perspective from Latin America". Fragile States or Failing Development? Canadian Development Report 2008. Ottawa: North-South Institute.

Bueno, Ramon et al. 2008. The Caribbean and Climate Change. The Costs of Inaction. Medford, Mass: Tufts University Global Development and Environment Institute.

Burt, Geoff. 2012. "From Private Security to Public Good: Regulating the Private Security Industry in Haiti". SSR Issue Papers 9. Waterloo: CIGI. 
Chesterman, Simon, Michael Ignatieff and Ramesch Thakur, eds. 2005. Making States Work. State Failure and the Crisis of Global Governance. Tokyo: United Nations University Press.

Corten, André. 2011. L'État faible. Haïti et République Dominicaine. Montréal: Mémoire d'encrier.

Deshommes, Fritz. 2006. Haïti: La nation écartelée. Entre 'Plan Américain' et projet national. Port-au-Prince: Éditions Cahiers Universitaires.

Dorvilier, Fritz. 2011. Gouvernance associative et développement local en Haïti. Port-au-Prince: Éditions de l'Université d'État d'Haïti.

Dupuy, Alex. 2005. Globalization, the World Bank, and the Haitian Economy. Franklin W. Knight and Teresita Martinez-Vergne eds. Contemporary Caribbean Cultures and Societies in the Global Context. Chapel Hill: University of North Carolina.

Dupuy. 2010. After the Earthquake. Recovery and Sovereignty in Haiti. LASA Forum. XLI (3): 13-15.

ECLAC. 2011. Indicadores sociales básicos de la subregión norte de América Latina y el Caribe. Santiago, Chile: CEPAL.

ECLAC. 2012. Economic Indicators and Statistics. Government Finance Statistics: Tax Revenue, http://website.eclac.cl.

Fatton, Robert. 2007. The Roots of Haitian Despotism. Boulder: Lynne Rienner Publishers.

Feldmann, Andreas, Miguel Lengyel et al. 2011. "Lost in Translation: ABC Cooperation and Reconstruction in Haiti". Journal of Peacebuilding and Development 6 (3): 45-60.

Feldmann, Andreas y Juan Pablo Luna. 2011. "The Problem: The State and Democracy in Latin America" [Online], http://www.statenessinlatinamerica.com/wp-content/uploads/2012/10/CONCEPTPAPER-MILENIO-IDRC-CONFERENCE-FINAL-NOV-2011-1.pdf [Accessed: 01/03/2012]

Fortin, Isabelle and Yves-Francois Pierre. 2011. La réforme de la police nationale et la construction démocratique en Haïti. Revue canadienne d'études du développement 32 (1): 64-78.

Fund for Peace. 2012. Failed States Index 2011. http:/ / www.fundforpeace.org/global.

Fund for Peace. 2011. The Fund for Peace Country Analysis Indicators and Their Measures. Washington: Fund for Peace.

Fukuyama, Francis. 2004. State-building: Governance and World Order in the 21st Century. Ithaca, NY: Cornell University Press.

Ghani, Ashraf and Claire Lockhart. 2008. Fixing Fragile States: A Framework for Rebuilding a Fractured World. Oxford; New York : Oxford University Press.

Gilles, Alain. 2010. L'enjeu de la stabilité politique en Haïti: L'expression d'un conflit de légitimité. Communication présentée au Congrès de la Latin American Studies Association (LASA), Toronto, Canada, 6-9 octobre 2010.

Guy, Ariane. 2012. Éducation en Haiti: Quel future pour les partenariats publics-privés? Unpublished MA thesis, University of Ottawa.

Herbst, Jeffrey. 2000. States and Power in Africa: Comparative Lessons in Authority and Control. Princeton NJ: Princeton University Press.

Hillman, Richard S. and Thomas J. D'Agostino, eds. 2009. Understanding the Contemporary Caribbean. Second edition. Boulder/London: Lynne Rienner Publishers.

Holly, Daniel. 2012. De l'État en Haiti. Essai. Paris: L'Harmattan.

ICG. 2011. Garantir la sécurité en Haïti: réformer la police. Briefing amérique latine/Caraïbes 26. Port-au-Prince/Bruxelles.

IHSI. 2003. Enquête sur les conditions de vie en Haïti. Port-au-Prince: IHSI. http:/ / www.ihsi.ht.

Maguire, Robert. 2011. "Goodbye to 'Pixie Dust'? A New U.S. Development Strategy in Haiti". Journal of Peacebuilding and Development 6 (3): 61-73.

Manigat, Sabine. 2010. Haïti: Un État en ruines, un peuple debout. www.cncd.be/spip.php?article1292.

Manning, R. and A. Trzeciak-Duval. 2010. "Situations of Fragility and Conflict: Aid Policies and Beyond". Conflict, Security and Development 10 (1): 103-131.

Marcelin, Louis Herns. 2011. "Cooperation, Peace and (Re-)construction? A Tale from the Shanties". Journal of Peacebuilding and Development 6 (3): 17-31.

Mata, Javier Fabra and Sebastian Ziaja. 2009. User's Guide on Measuring Fragility. Bonn and New York: DIE/UNDP. 
Ministère des finances. 2012. Haïti: Indicateurs de performance du système fiscal. Port-au-Prince: MFIN.

Muggah, Robert and Athena Kolbe. 2012. Haiti's Urban Crime Wave? Results from Monthly Household Surveys. August 2011-February 2012. Rio: Instituto IGARAPE.

Muggah, Robert and Athena Kolbe. 2011. Securing the State: Haiti Before and After the Earthquake. Small Arms Survey 2011. Cambridge/Geneva: Cambridge University Press/Small Arms Survey.

Newman, Edward, Roland Paris and Oliver Richmond, eds. 2009. New Perspectives on Liberal Peacebuilding. Tokyo/New York: UN University Press.

OECD/DAC. 2011. Supporting Statebuilding in Situations of Conflict and Fragility: Policy Guidance. Paris: OECD.

Office of the UN Special Envoy for Haiti. 2012. Analysis Shows 52.9 Percent Disbursement Rate for Haiti Recovery Among Public Sector Donors. http://www.haitispecialenvoy.org

ONI. 2011. Nombre d'inscrits au niveau national de septembre a décembre 2011. Port-au-Prince: ONI, http://oni.gouv.ht.

Pages, Carmen. 2010. The Age of Productivity: Transforming the Economies from the Bottom Up. Washington: Inter-American Development Bank.

PAHO. 2012. Vaccination Coverage by Vaccine. http://www.paho.org

Peterson, Spike. 1992. Gendered States: Feminist (Re)visions of International Relations Theory. Boulder/London: Lynne Rienner Publishers.

Richmond, Oliver. 2011. A Post-Liberal Peace. London/New York: Routledge.

Schwartz, Timothy T. and Yves-François Pierre. 2011. Building Assessments and Rubble Removal in QuakeAffected Neighbourhoods in Haiti. BARR Survey. Final Report. Washington: US AID.

Seitenfus, Ricardo. 2011. "The Nature of Haitian Politics and International Challenges". Journal of Peacebuilding and Development 6 (3): 85-90.

Shepherd, Laura. 2008. Gender, Violence and Security: Discourse as Practice. London/New York: Zed Books. Skocpol, Theda. 1985. Bringing the State back In: Strategies of analysis in Current Research. Peter B. Evans et al. eds. Bringing the State Back In. Cambridge: Cambridge University Press.

UNSG. 2012. Report of the Secretary-General on the United Nations Stabilization Mission in Haiti. S/2012/128. 29 February.

Wargny, Christoph. 2004. Haït n'existe pas, 1804-2004: deux cents ans de solitude. Paris: Autrement.

World Bank. 2011. Conflict, Security and Development. World Development Report 2011. Washington: World Bank.

Young, Crawford. 1994. The African Colonial State in Comparative Perspective. New Haven: Yale University Press.

Zanotti, Laura. 2010. "Cacophonies of Aid, Failed State Building and NGOs in Haiti: Setting the Stage for Disaster, Envisioning the Future". Third World Quarterly. 31(5): 755-771.

Zéphyr, Pierre Martin D., Pierre, Yves-François et Cordova, Abby. 2006. Culture politique de la démocratie en Haïti: 2006. Port-au-Prince: LAPOP/USAID.

Zéphyr, Pierre, D. Martin and Mitchell Seligson. 2008. Democratic Values in Haiti, 2006-2008. Nashville: LAPOP/Vanderbilt University.

Zéphyr, Pierre, D. Martin, Abby Cordova and Mitchell Seligson. 2011. Haiti in Distress: The Impact of the 2010 Earthquake on Citizen Lives and Perceptions. Nashville: LAPOP/Vanderbilt University.

Stephen Baranyi is an Associate Professor with the School of International Development and Global Studies at the University of Ottawa. He currently works at the nexus of development and (in)security -on issues like peacebuilding, security system reform, development cooperation and gender in equality in fragile and conflict-affected states, especially in the Americas.

E-mail: stephen.baranyi@uottawa.ca 